Iryna Nesen. Semiotic codes of the costume in the political theater performances in the USSR...

DOI https://doi.org/10.30525/978-9934-26-065-0-12

Iryna Nesen,

Candidate of Historical Sciences,

Assistant Professor of the Fine Art Expertise

Department of the National Academy

of Culture and Arts Management, PhD student

inesen@dakkkim.edu.ua

ORCID 0000-0002-9804-9659

\title{
SEMIOTIC CODES OF THE COSTUME IN THE POLITICAL THEATER PERFORMANCES IN THE USSR OF THE 1930S
}

\begin{abstract}
The purpose of the publication is to track and analyze semiotic codes in the political theater costumes of the USSR in the 1930s, when the state was in the process of forming a totalitarian-ideological model. Methodologically, the study is based on a combination of the hermeneutics principles, formal and semiotic types of analysis. The novelty of the study is based on significant gaps in the study of theatrical costume in Ukrainian performances of the Soviet period. Conclusions. Analysis of the performances of Ivan Mykytenko (18971937) and Oleksandr Korniychuk (1905-1972) allows us to identify significant changes in all elements of the performance - the plays themes, the composition of dramatic productions, the plot development, the solution of stage space and characters. Art design was the most valuable part of the performances. After all, in the 1930s, leading avant-garde artists continued to work in theaters. Vadym Meller, Anatoly Petritsky, Alexander KhvostenkoKhvostov, as well as their students, who formed the next generation of theater artists, were among them. The characters costumes corresponded to the specificities of different social classes clothes of that time. Negative characters were determined by individual details of clothing, general stylistics, make-up and role figure in the action and by the end of the play they had to disappear from public life by one means or another.

Keywords: political theater, industrial clothes, body code, behavioral code, texture of theatrical dressing.
\end{abstract}

Introduction. The development of the national theater in the 1930s is associated with the formation of the socialist realism method, which at this time 
begins to influence all branches of culture and art. After many stage projects of the Ukrainian avant-garde, carried out during the 1920s, the change of the political vector in Soviet Art led to a rapid narrowing of the work methods in the Ukrainian theatrical space. The countdown to this phenomenon was 1929, which embodied a major turning point in the life of the USSR in general and Soviet Ukraine in particular. In our study we will systematically trace the features of the theatrical costume style in domestic performances and establish changes in its typology. It should also be noted that a thorough stage costumes study of the Ukrainian theatrical chronotope will allow filling in numerous gaps in this topic.

It is important for us in this article to analyze the semiotic codes laid down by artists in political performances theatrical costumes that took place on the stages of various USSR theaters in the 1930s and corresponded to current issues of government - collectivization and modernization. After all, there are significant gaps in the stage costumes study, their role in the formation of the actor's style, the figure of the play for performances of the entire Soviet period. Their gradual filling will allow establishing the typology of theatrical attire, its periodization according to the peculiarities of formation and significance for the general image. Disclosure of the costume inner essence, the artist's approaches in determining its style for different groups of characters starts from the content of the play and the peculiarities of its creation.

Analysis of research and publications. Scientific works and separate publications on the outlined problem in domestic science are essentially absent. However, an important basis for our article is theatrical and art studies of generalized content [14]. They reveal the main trends of many theatrical phenomena and processes, thus allowing you to go deep into little-known material. The historical events of the 1920s brought to the theatrical art of Soviet Ukraine the idea of the need to create a new model of theater, namely, proletarian and therefore revolutionary. This meant a paradigm change in its existence. In the 1920s, from the domestic plots developed by the Theater of Coryphaeus from the beginning of the twentieth century, the theaters of the USSR moved to depicting various political events. This is how the model of political theater is formed.

The well-known national scholar Olexander Klekovkin formulated and systematically explored the concept of "political theater" as a type, outlining its essence in the following description: “... Theater, which seeks or at least imitates 
Iryna Nesen. Semiotic codes of the costume in the political theater performances in the USSR...

the desire to freely discuss political issues in their performances (i.e. governmental problems), but in the political forces struggle for power is on the side of a party" $[4,637]$. He also deduced the historical periodization of this concept, highlighting four periods of its development from antiquity to the end of the twentieth century [4, 637-651]. The 1920s marked the beginning of the third period of political theater in various countries of Western Europe and the USSR [9].

The researcher Nellie Kornienko stated the model of political theater in the approaches of the leading director of the era, Les Kurbas, and the activities of his "Berezil" theater: "Political theater is cruel. Any political one. It demands a myth. That doesn't mean it's bad. This means only that political theater arises in such historical moments, when most appeal to openness, to calling things by their names, to the resurrection of the myth of Goodness and Justice, to the discovery of subtle ethics for the sake of straightforwardness" [5, 196]. Scholars consider 1922-1926 to be a period of active application of the political theater model in the Berezil activity.

Another important analytical source that reveals the changes nature in methods and approaches in the preparation of the most important performances of the Berezil Theater in the 1920s and 1930s is the Anna Veselovskaya's work. By this, the author reconstructs the features of its twelve projects from "Black Panther and Polar Bear" (1917) to "McLean Grass" (1933) and gives an overview of the art criticism associated with them [3].

Results and discussion. For the theatrical art of the USSR, this period is associated with the birth and strengthening of the totalitarian power model Stalinism, which was concentrated between 1929 and 1953. Starting 1929 the theatrical art of Soviet Ukraine functioned in difficult conditions of the country modernization, which took place according to the incorrectly formed state plans; forced collectivization of private agriculture; constant search for internal enemies of the Soviet system, which led to numerous lawsuits and criminal punishments of the Ukrainian elite members.

As a result of these political processes the theatrical art of the USSR changed its repertoire. In one of his letters (November 28, 1929) to M. Tereshchenko, I. Mykytenko wrote: "Circumstances are extremely unfavorable. There is no repertoire at all" [16, 2]. The supporters of theatrical socialist realism saw the way out of this situation in the renewal of old plays and the creation of completely new 
plays that had just been written. First of all, in the ideologically pro-government context, the works of the founders of the Theater of Coryphaeus were now being reworked. One of the clearest examples of this is the diary notes of director Mark Tereshchenko to the new version of I. Karpenko-Kary's play "Vanity". The classical line of opposition between the spiritual worldview of the Ukrainian masters, which preserved the national tradition, the emptiness of the Russian bureaucracy in uniforms of various calibers, has been replaced by a proletarian class approach. M. Tereshchenko calls I. Karpenko-Kary's author's view "a sweet powder of Little Russian romance" $[18,163]$. According to the socialist version the representatives of the national elite traditionally dressed in embroidered shirts are harmful bourgeois-nationalist elements or landlords-exploiters, rural kulaks. This approach begins to quickly recode the visual images of the characters of the play from positive to negative.

At the same time, a new type of playwright appeared at the turn of the 1920s and 1930s. I. Mykytenko and O. Korniychuk were the most notable among them. They create "topical socialist drama", which aims to make the theater the engine of creating the type of people of the future. A special place here is occupied by the image of the woman, who arose as a result of the proletarian culture progress. All the features inherent in the heroines of the past recede into the background. Their place is taken by revolutionary characteristics of determination, intransigence and ruthlessness towards enemies. New means of expression and the creation of a new acting style were needed to bring out such female types and characters in the play. In fact, the 1930s were a time of a new paradigm formation for the creation of the play, the ratio of its content and form, the revision of the costume functions.

Let's recall that the costume of a dramatic character, as a kind of document, informed the audience about the basic qualities and state of mind of its owner. The researcher Peter Bogatyrev was one of the few to analyze theatrical dressing in terms of semiotics. In his discourse, he noted, in particular, that in contrast to real-life dressing, the stage one has fewer constitutive (definition - I.N.) meanings, usually two or three features that are related to the context of a particular dramatic situation. However, the scholar acknowledged that theatrical costume is a complex sign that usually characterizes both ethnicity and social affiliation. Among other things, P. Bogatyrev identified two semiotic categories that are important for the analysis of the form and content of scenery, elements of scenography and costume - 
Iryna Nesen. Semiotic codes of the costume in the political theater performances in the USSR...

"sign" and "sign of the thing" $[1,8]$. So, to study the question, let's define a triad of theatrical elements: "play - performance - actors in images" in terms of semiotic codes of stage costumes.

To solve this goal, let us turn to a number of theatrical performances staged during the selected period based on I. Mykytenko's plays "Dictatorship" (1929) and "Girls of Our Country" (1933), "Marusya Churai" (1934), "Solo on the Flute" (1935) and O. Korniychuk's "Banker" (1937), "Bohdan Khmelnytsky” (1939). To accomplish this task, a brief analysis of the texts of the plays should be made and compared with the stage versions, which at least partially reveal the archival photographs. Having selected in this way, the created images of the characters, their costumes, makeup, features of the play, define their semiotic codes and meanings. In this way, the actual material will be gradually superimposed in terms of different semiotic codes, primarily physical and behavioral. Each code will reveal the mechanism of transforming the text essence into the stage images. Analysis of the theatrical costume role in the chronological continuity of the creation of performances will also clarify the stages of its stylistic incarnations in the various artists' artworks.

The "Dictatorship" play, which premiered at the Odessa Theater (directed by M. Tereshchenko), took a strong position in the Ukrainian theatrical repertoire for many years. In his comments to the play, I. Mykytenko explained its essence as a struggle between the old and new worlds, emphasizing the following: "The play should be set in the tones of conditional realism, without falling into naturalism society" $[15,1]$. Previous researchers have noted that the author's guidelines on the political views of the main characters of the play started a flywheel of "replication". The only one who avoided this in his production was director Les Kurbas. I. Mykytenko's construction of a rigid scheme-construction prompted L. Kurbas and V. Meller to embody a number of extraordinary constructive techniques on the stage. Analyzing the play "Dictatorship", in the production of the "Berezil" Theater, critics noted its well-thought-out operatic rhythm and recitative in the performance of texts; a composition based on the principle of disproportion, which arose from a combination of inactive actors and a moving stage with a complex system of moving tablets. As a result of such complicated scenography, there was a symbolism of space, expressively segmented in verticals and horizontals, in contrast to the Soviet method of linear space disclosure in other theaters performances [5, 296, 298, 304]. 
Each of the characters was provided with his own imagery, in his own way embodied involvement in the camps of the old or new forces. Among the heroes who built a "new life" we see workers and various rural poor, in particular the leadership of the Gorbachev village council, where there was fighting for bread. The first group during development of a plot is represented by the shipbuilder from the Nikolaev plant Grigory Dudar. Arriving in the village, he gives impetus to the agitation to hand over the grain of the new harvest. His support group consists of Komsomol members Oksana Nebaba, Pavlo Koval and Nechay.

To mark the characters of both groups, L. Kurbas and V. Meller first of all used the general codes of their dressing. Boiler workers are dressed in overalls (industrial clothes) developed by the designers of that time. This dressing, in various subtypes, was formed from the early 1920s, becoming the object of modeling in the artworks of individual artists. Let's remember the so-called "normal clothes" of Vladimir Tatlin, everyday clothes models of Alexandra Exter, "overalls" for workers of different professions of Grigory Miller, Alexander Rodchenko and others. Overalls in the 1930's embodied the future life. Rubber boots were added to them in the heavy production conditions. The entire working mass in the play is dressed comfortably for work. This functionality in the "Dictatorship" play embodies a new futuristic aesthetic, displacing the old one, which was based on the reception of color and ornamental decoration. The workers also wear leisure clothes on the stage in addition to work clothes. A jacket, which in the performances of the 1920s was still associated with bourgeois life, became a permanent part of it. Thus, in the remark before the first act, I. Mykytenko noted that G. Dudar, having finished his work, changed into a blue jacket $[7,27]$.

In accordance to the clothing style of the era and the social class, the stage costumes of the leadership of the Gorbachi village are defined, this protected the interests of the poor. Komsomol members Oksana Nebaba, Pavlo Koval, chairman of the District Party Committee Velychko, Chairman Raivyk Chabanenko, chairman of the village council Gorokh, Nechay, Cherneha, poor Nastya in the play are dressed in clothes that replaced the traditional village clothes. The men had worn dark pants and jackets with pockets. The women also had jackets and spacious simple skirts. The image of Oksana Nebaba in performances of various theaters was defined in two types - more rigid, politicized (the heroine is dressed in a leather jacket, tightened under the belt - Gakkebush in "Berezil") 
Iryna Nesen. Semiotic codes of the costume in the political theater performances in the USSR...

or common (white shirt, head tied with a light linen scarf - Natalia Uzhviy in the performance by the Ivan Franko Kyiv State Drama Theater).

In the oppositional characters group there are all those who seek protecting the traditional agrarian system. Therefore, they are dressed in folk costumes. Their linen clothes, without any decorations, embody devotion to rural life. At the same time, the use of vests as a marking part of the entrepreneurs costume of different levels in the early twentieth century, a hint of wealth or the desire for wealth (like Maloshtan) is common in the clothes of "traditional" men (Chirva, Piven, Syrovatka). However, let us pay attention to the fact that their clothes are completely unrepresentative and dark. In terms of texture and style the costumes in the play created by L. Kurbas, in reality did not depict any wealthy peasant. Instead, both the "kulaks" and the "sub-kulaks" in the play had to embody the negative - to demonstrate their hostility to the Soviet government and the establishment of a "proletarian dictatorship" model.

The systems of female images from the group of kulaks or sub-kulaks are solved differently. They highlight the age context. Senior women are in traditional dressing. The daughter of the "money grubber" Piven Paranka stands out from the younger ones. As the marriageable girl, she, according to the author's text, is dressed "with a claim", "she has a colorful shawl on her shoulders." I. Mykytenko also emphasized the fashionable accessory in her dressing - a fan with which sheflaps flies away. L. Kurbas and V. Meller turned the author's concept "with

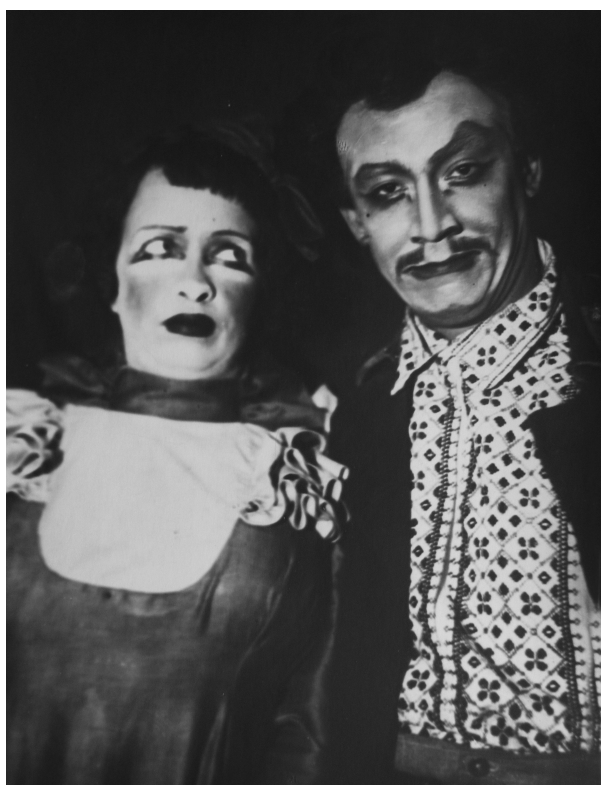

Fig. 1. Gusak and Paranka. The Dictatorship play. Artist W. Meller. "Berezil" Theater. 1930 CSAMLA of Ukraine. F. 657, Op. 1, Stor. units 242 
a claim" into a dress with numerous frills, referring the audience to the realities of fashion of the NEP times and creating a deeply vulgar costumed image.

In addition to the dressing nature, the characters identification is clear by a number of semiotic codes - body, behavioral and regulatory. The body code emphasizes the play picture of each of the characters, their gestures, poses, facial expressions. W. Meller developed hairstyles and makeup for the actors with the help of body code techniques. It was possible to create images of sometimes cunning and sometimes short-sighted characters in combination with caricature behavior, emphasis on facial expressions, enhanced gestures. The figurative dissonance between the "poor" and the "kulaks" was intensified by the symbolic possibilities of mise-en-scène, their figures with the demonstration of certain social stereotypes. Instead, the aesthetic context in the classical sense of the term in the play was completely leveled. In terms of the image modeling principles in two antagonistic groups, we also see a difference in their general interpretation graphically modeled characters from the "new world" in monochrome, with linear silhouettes, overalls, which are interpreted by the author as hero-mass and imagesspots - as illustration of an old life.

Another play by I. Mykytenko "Girls of our country", defined by genre as a lyrical comedy, was written in the period of 1932-1933. At the end of the publication the author noted the places of its writing: Dniprelstan, Kharkiv, Kyiv, Yalta, Kharaks. In the center of the plot - the construction of the first hydroelectric power plant in the USSR of Dniprelstan. The characters in the play form groups again Komsomol girls, led by Maria Shapiga, become participants of the construction, performing men's work on concreting the structure. Workers are divided into "Komsomol members", "individuals" and "old workers". Engineer Lototsky and his wife act separately in the play; and American engineer Mr. Haywood with his wife and daughter. The introduction of the person of an American specialist in the construction of DniproHES (Dnipro Hydroelectric Power Station) is an example of the introduction of a documentary fact into the dramatic work plot.

The main line of the play composition is the love of the Komsomol foreman Shmetelyuk for Lototskaya (the engineer's wife) and the relations between them that arise and develop. Lototskaya is defined in the play as the only completely negative character. It is the enemy of the Soviet power and proletarian culture. Hence is Shmetelyuk's hesitation, his internal struggle and problems with the team 
Iryna Nesen. Semiotic codes of the costume in the political theater performances in the USSR...

and management and finally a personal victory over the wrong feeling and return to his team. At the end of the play, Lototska finds herself in complete isolation even her husband leaves her.

The play premiered at the Kharkiv Theater of the Revolution in 1933. It was directed by Oleksiy Dyky and artist A. Petrytsky. The play was later staged in many theaters of the USSR. It was staged separately in Moscow at the All-Union Theater. In the premiere production, we see a return in its design to the scenery, the nature of which has changed significantly from naturalistic to conventional. It shows the achievements of the previous era constructivism. For each action, the artist created a separate environment, created on a turning circle: the open space of the square; Lototsky's apartment; a room in an employee dormitory; construction

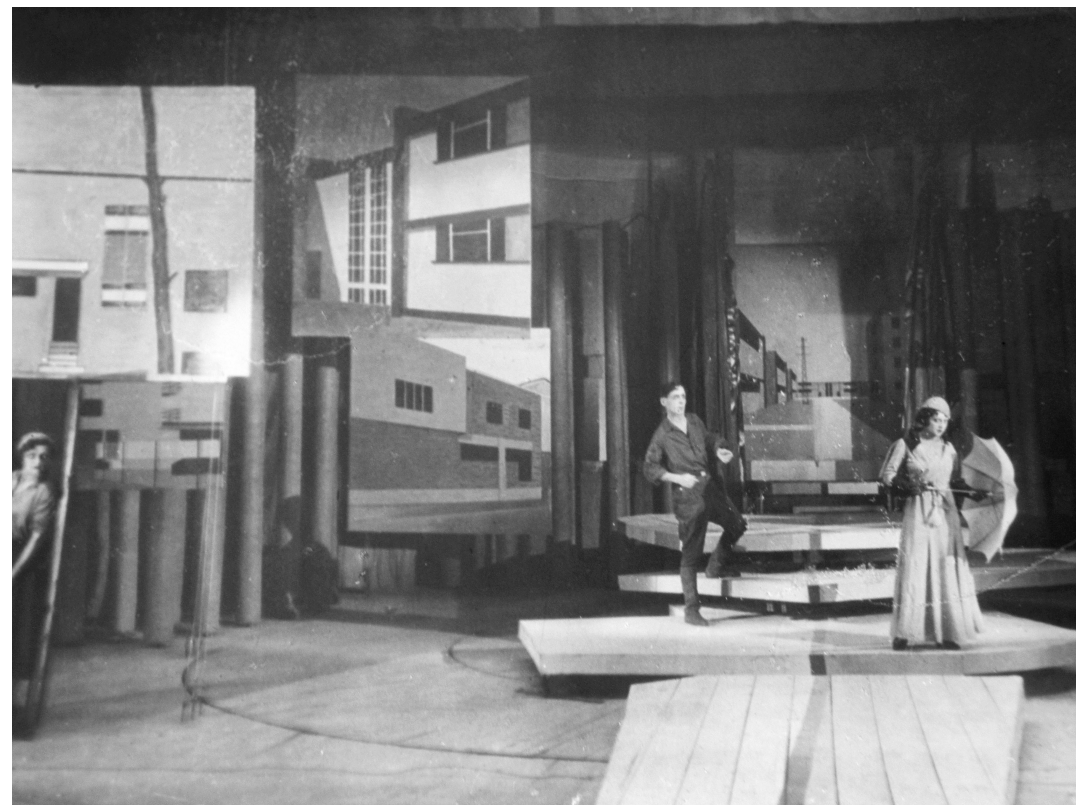

Fig. 2. Scene from the "Girls of our country" play. Artist A. Petritsky.

Kharkiv Theater of the Revolution. 1933

CSAMLA of Ukraine. F. 657, Op. 1, Stor. unit 257. 
of Dniprelstan. The podiums of different heights, made of white boards were located on the stage in all actions. They defined the outlines of the city square and in the rooms - divided the interior area into parts for different purposes - the entrance, bed, living room with table by the window and so on. The Lototskys' apartment housed a conditionally large window through which the landscape could be seen. A. Petritsky created it on the principle of decorative panels. In the employee dormitory room the room walls are modeled by rhythmically arranged white rectangles of shields. The space of the structure is formed by densely placed vertical black pipes, which are arranged in a semicircle along the stage edge. This approach to the creation of scenography is characterized by conventionality, neat expressiveness. In each act of the play there were objects in the interior that were visible, which created the mood and circumstances of the environment.

In the first act, when Masha meets Lototska with Shmetelyuk on the road the antagonism of meanings on the costume attributes emerges in the images of these two women. Masha has rubber boots for working on concrete. Lototskaya has

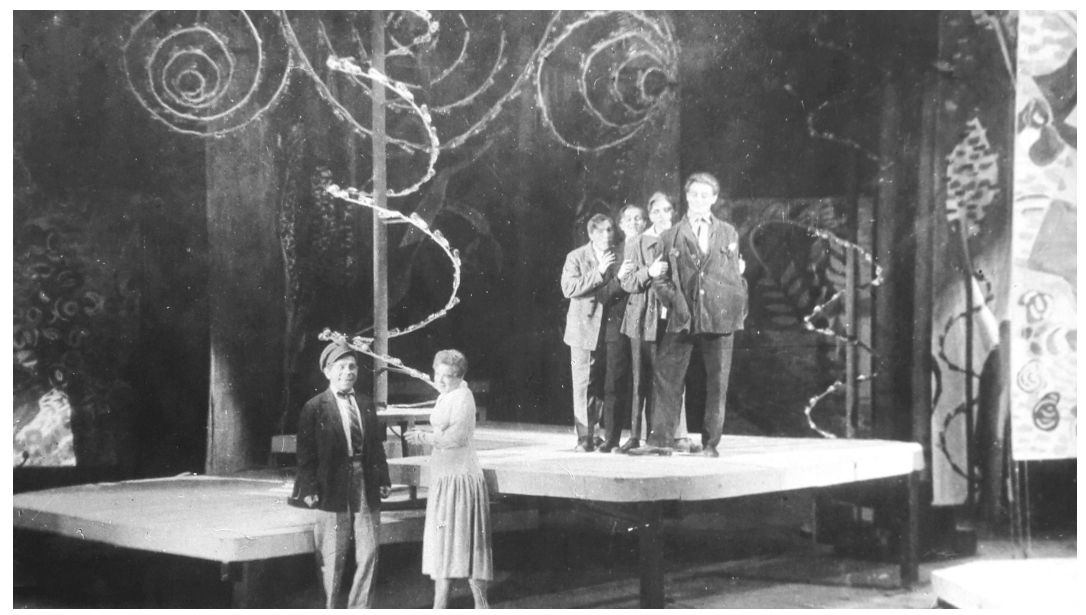

Fig. 3. Scene from the "Girls of our country" play. Artist A. Petritsky. Kharkiv Theater of the Revolution. 1933 CSAMLA of Ukraine. F. 657, Op. 1, Stor. unit 257. 
Iryna Nesen. Semiotic codes of the costume in the political theater performances in the USSR...

gloves as the embodiment of her bourgeois taste. In the play text the author also reports that Lototska uses men's perfume "Chypre", alluding to her attraction to bohemianism. In the following steps, when Lototska and Shmetelyuk meet again, she is mostly in a white (light) dress, added by an elegant hat and umbrella. Instead, at the moment of a sharp ideological conflict with her husband and later with Shmetelyuk, she has a black dress. The face becomes predatory.

A. Petritsky differentiates men's clothing in the same way. Overalls are among the working clothes of Komsomol members and when it is bad weather rubber raincoats. The latter are also a demonstration of the new outfit emergence in the work environment. The color of the raincoats hints at the professional differentiation of their owners. Engineers have light, foreman - dark. In the general perception of the scene of the quarrel between Shmetelyuk and the team over the situation with Lototskaya, the clothes of the characters in spots organize the rhythmic order of the room. Each of the workers has something white in a suit or details - a shirt or a towel. They emphasize the foreman dark figure in a light semicircle. The "individuals" - a folk costume consisting of dark pants and the same color jacket with pockets. They wear jackets and light shirts during the weekends.

In this way, A. Petritsky builds, though not complicated, but symbolic structure. In it, he builds the necessary visual accents that inform on the character essence. At the same time, the image of a new life woman-builder is repeated from play to play. It is written in extremely laconic strokes - a scarf on her head, overalls, rubber boots. Everything is for hard work, which is treated as honorable. The new quality - masculinity - is clearly visible in the images of girls laying concrete. Instead, in a private atmosphere, the artist dresses girls in a modern silhouette of the 1930s, which features a braided cut that widens the skirt to the bottom and emphasizes the waist and shoulders, creating an image of a new generation of young people.

Simultaneously with the works of everyday content I. Mykytenko tries to return to the theater national performances in form, modernized in content. He writes a play-remake based on the plot of M. Starytsky's drama "Oh, Hryts, don't go..." about the heroic girl Marusya Churai. This restores interest in historical plays. In addition to the text of M. Starytsky, I. Mykytenko apparently used a version of the play of the same name by Ostap Vyshnya, written based on M. Starytsky in 1925. The author's writer fund keeps his manuscript of 39 sheets [16]. The premiere of 
the play "Marusya Churai" took place in the season of 1934-1935 on the stage of the Kharkiv Theater of the Revolution staged by M. Tereshchenko. Mykola Burachek was an artist in it. Marusya was played in different seasons by actors Cleopatra Tymoshenko (she is also in the role of Natalia in "Solo on the Flute") and Anna Yanushevich.

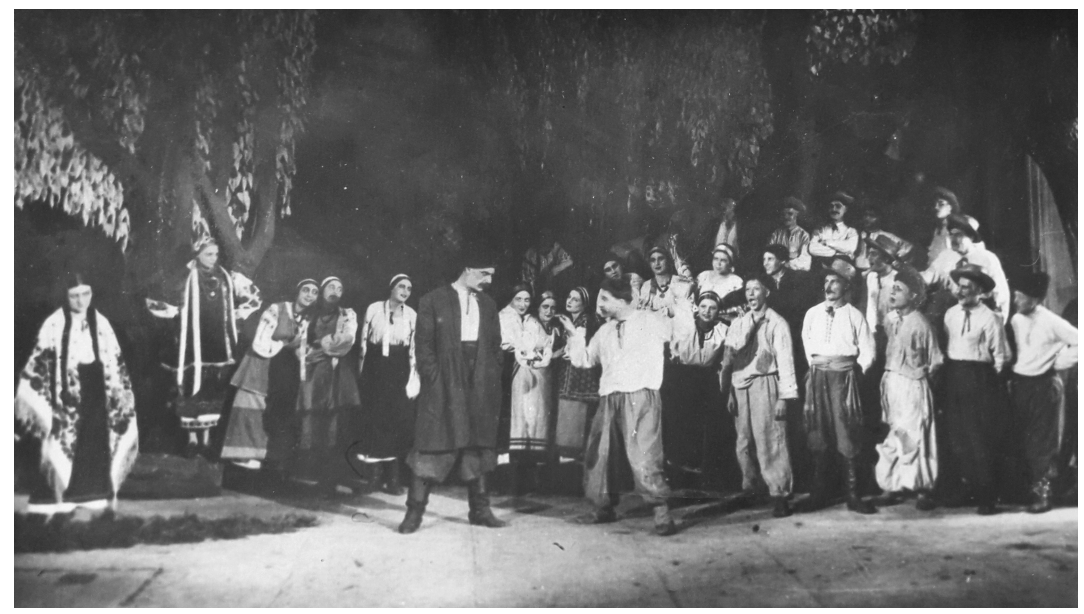

Fig. 4. Scene from the play "Marusya Churai". Artist M. Burachek. Kharkiv Theater of the Revolution of 1934 CSAMLA of Ukraine F. 657, Op. 1, stor. unit 263.

This production brought back to the stage the classic techniques established at the time by the Theater of Coryphaeus and confirmed the foundations of academic drama. The audience was again offered a folklore story-legend with a household basis, decorations depicting the Ukrainian village in conventional buildings, traditional interiors and costumes. The stage costume here was a quotation from the traditional costumes of the 19-20th centuries. These were typical folk costumes - more elegant, composed on the basis of embroidered shirts and homemade sheets, as well as more modest - for poor girls, where a white linen shirt was added by a simple skirt made of store fabric. Traditional events, celebrations, debates, etc. Thus, the ethnographic color was restored in the performances of the 
Iryna Nesen. Semiotic codes of the costume in the political theater performances in the USSR...

1930s. Playing their roles, the actors no longer communicated with the audience, but acted in the play on the restored principle of the fourth wall.

The premiere of another performance of I. Mykytenko's "Solo on the Flute" took place at the Kyiv State Ukrainian Drama Theater named by I. Franko in 1935. At the same time this play was staged at the Odessa State Ukrainian Drama Theater named after October Revolution. Its plot by form creation, in opposition to previous plays, was marked by certain humanism. The author portrayed in it the world of scientists who worked at the Research Institute of Culture and Life. However, as the story unfolds, it becomes clear that two opposition groups are emerging at the institute - zealous supporters of Soviet power led by the institute's party committee secretary Fedor Veresay and its hidden enemies, who have consolidated around newly elected academic secretary Hryhoriy Yarchuk. This group is trying to win over the director of the institute, Serhiy Berezhny.

The theatrical costume in this play is a replica of that time everyday clothes. $\mathrm{He}$ is not a marker of either the positivity or negativity of the characters. Hostility is represented here in two ways - the use of the Western Ukrainian dialect or

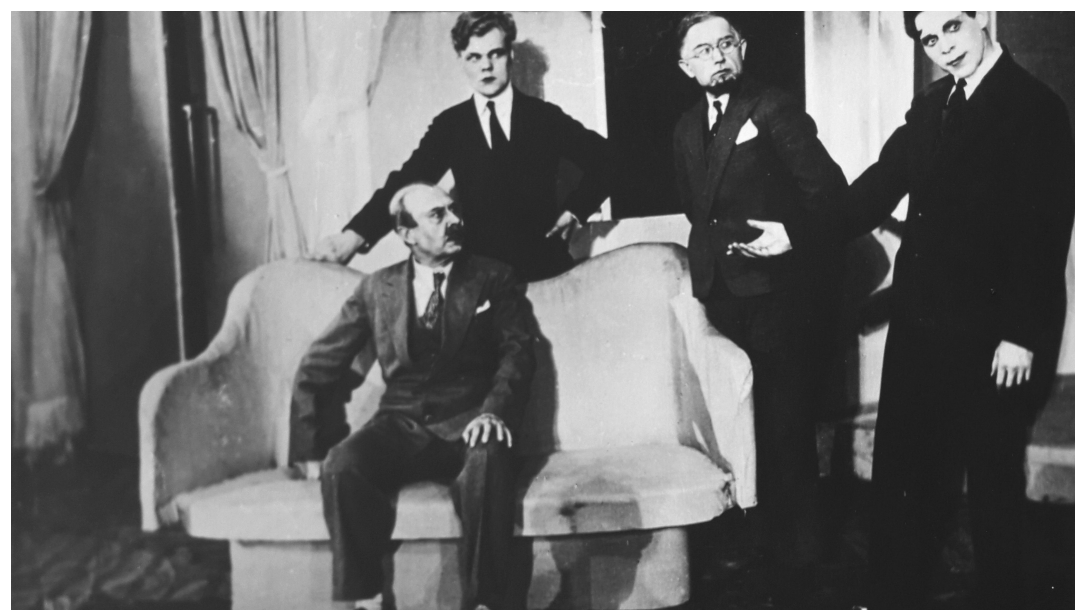

Fig. 5. Scene from the "Solo on the flute" play.

Odessa Theater of the Revolution, 1935

CSAMLA of Ukraine F. 657, Op. 1, Sor. unit 265. 
Western Ukrainian surnames (Ruzhevsky, Khortevych); and the character style, which demonstrates his unpleasant appearance (facial expression, cartoon hairstyle, grotesque pose). This is how we see G. Yarchuk. Positive heroes either had ancient Cossack surnames or were dressed in embroidered shirts (F. Veresay), as in the play of 1959, staged at the Moscow State Russian Drama Theater named after O. Pushkin.

In 1937 another performance based on O. Korniychuk's play "The Banker" premiered. It created a gallery of exceptionally positive characters who lived and worked in a provincial Ukrainian town. The characters in the play are very simple. Therefore, among them it is difficult to distinguish between major and minor. There is also no "hero-mass" or opposition group. However, the title of the work highlights Roman Kruch, who heads the bank. The plot simultaneously unfolds three lines of love: Tura and Chaika (daughter of Kruch), Kapusta (astronomer) and Tanya and Kruch himself, who met his wife Taiga, who left him many years ago. In this way, the play re-emerges the theme of a woman's new status, her independence.

The vast majority of the characters are dressed in the clothes of that time. However, from the dialogue between Tur and Chaika in the first act, we learn about the spread of knitted clothes in household use, which are produced by the factory where Chaika works. The embroidered shirt in the play is already the clothes of a positive hero from the countryside. Bezshtanko wears it in a suit as a representative of the "progressive" peasantry of the united collective farms. This is how his image was performed by various actors - Kost Kulchytsky and Dmytro Milyutenko in the Ivan Franko Theater. Some historical facts of the past are also introduced into the outline of the action through the accessories to the costume. Bezshtanko has a watch given to him by his father Bozhenko. Taras Kapusta (actor Mykhailo Dosenko) and Kruch (actor Viktor Dobrovolsky) are not afraid to wear ties, which in previous years had a sign of bourgeoisie.

The artist also identifies Taiga as the main female character with the help of the costume. She is dressed exclusively in elegant well-thought-out outfits, which she changes in every action. The heroine also uses accessories that in the past were the prerogative of ladies from the upper-class society. It is a hat with a veil or velvet around her neck (Natalia Uzhviy).

The ideological realm dominates not only in the plots of Soviet drama, but penetrates into the historical plots of the past. This fate befell the play 
Iryna Nesen. Semiotic codes of the costume in the political theater performances in the USSR...

"Bohdan Khmelnytsky" based on the newly created play by O. Korniychuk (1936-1938), which caused quite a lot of political discussion in the historical science of that time [13]. With the intensification of the confrontation in international politics between the USSR and Poland, the problem of the Ukrainian Cossacks struggle under the leadership of Bohdan Khmelnytsky with the PolishLithuanian Commonwealth became new. The play was recommended for staging and in 1939 the premiere took place simultaneously in Kharkiv at the Ukrainian Drama Theater named after T. Shevchenko (March) and in Moscow at the Maly Theater (April). Then it was staged at many theaters in Ukraine [6]. In the following decades the play entered

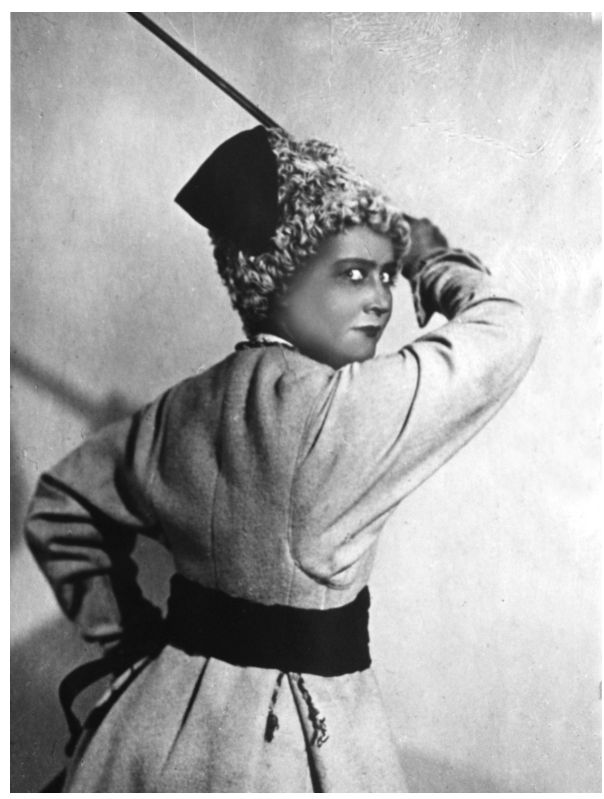

Fig. 6. Solomiya (V. Obukhova) from "Bohdan Khmelnytsky" play. The Maly Theater. Artist A. Peritsky, 1939 CSAMLA of Ukraine F. 616, Op. 6, Stor. unit 482. the repertoire.

From an artistic point of view the staging of "Bohdan Khmelnytsky" play restored the tradition of making carefully thought-out and skillfully executed theatrical costumes based on authentic historical models. V. Meller prepared them for the Kharkiv play. A. Petritsky did it for the Maly Theater. Since D. Yavornytsky was a consultant in the process of creating the play, his advice partly influenced the characters style.

Let us touch the preserved materials for the play costumes at the Maly Theater, made by A. Petrytsky from the collection of the Museum of Theater, Music and Cinematography of Ukraine. The principles of creating highly artistic samples of them created on a historical and everyday basis, the artist preserved 
in the era of "socialist realism". Therefore, preparing dozens of sketches, the artist acted as a profound thoughtful researcher of Ukrainian history, life in a variety of details and images. Working with watercolors and pencils he created several dozen sketches for the costumes of the Sich Cossacks, colonels and the hetman himself during the first stage of the National War of 1648.

The ancient baroque culture is embodied in each image, embodied in fabrics decorated with national ornaments, historical accessories (powder keg, cradle, purse) and attributes (warder, hatchet, tambourine). It is through the costumes that the artist presents the characteristics of the Polish nobility, individual representatives of the Crimean Tatars, Germans and others. He clearly reveals the features of the designs and textures of such outerwear forms as dressing gown, robe, fur coat, caftan, frock, retinue, felt cloak. The same was with hats. His characters are dressed in hats, helmets, scarves and more. The Polish elite is distinguished by fur-lined clothes, feathers on hats, yellow French-style shoes (boots) and precious fabrics. Prince Chetvertynsky, voivode Adam Kysil, prince Koretsky, crown hetman Mykolay Potocki are dressed in precious fur coats; Field Hetman Martin Kalinowski has a fur cape in his suit; Colonel Charnetsky had a fur-lined robe. Sometimes representatives of the petty nobility wore Europeanstyle pants (manager of Count M. Pototski). Representatives of the Crimean Tatar military nobility are marked by striped or gold-plated clothing (Pasha Aga Osman has such a caftan), a dressing gown, conical hats, striped shoes with upturned noses and weapons inlaid with jewelry. The artist carefully reproduces the complex textures of fabrics in the costumes of representatives of the nobility from other ethnic groups. An example of this is the costume sketch of the Moscow kingdom representative, Prince Trubetskoy. It has a noticeable texture of precious fabric with a small floral pattern of complex tones, which combines green, blue, burgundy and red. The watercolor sketch conveys the smallest characteristic details of that time cut, in particular the shape of the sleeve heads.

Ukrainian Cossacks are dressed in bright, often floral, traditional clothes, hats with slings, red or yellow shoes. The image of B. Khmelnytsky is presented without detailed modeling, with an emphasis on the geometrized large volume of the body, a large head and is perceived as monumental. This image, no doubt, is intended for use on the reception stage of weighting due to the multi-layered system with a predominance of red. Such carefully thought-out variability of clothes forms, 
Iryna Nesen. Semiotic codes of the costume in the political theater performances in the USSR...

details and elements is combined by A. Petritsky with the decorativeness reached by color. After all, in a separate costume you can see the traditional folk combination of local colors: red and green, red and purple, yellow and blue, gray and blue, gray and green, blue and green.

Due to mass monumental, staged performances A. Petritsky managed to embody one of the leading functions of theatrical costume, which was emphasized by the famous theater critic Patrice Pavis: "What is important here is the change of costumes during the performance, the meaning of contrasts, the auxiliary function of shapes and colors. The internal system of this relationship is (or should be) absolutely coherent so that the public can read the plot. However, the attitude to external reality is extremely important when the play should capture the viewer and encourage him to compare with the historical context. The choice of costumes inevitably depends on the coordination and tension between the internal logic and the external reference of the performance: the number of clothing options in this case is unlimited. The spectator will catch a glimpse of everything that is reflected on the costume as the bearers of the signs of action, character, situation and atmosphere" [10,233].

Conclusions. The change of "big politics" in the USSR for the creative life of the theater began to control the drama and the process of creating plays. From the standpoint of their science, literary critics called I. Mykytenko's plays kitsch: "Every year he produced a play in accordance to the latest resolution of the Central Committee of the party. If it is about collectivization - you have a "Dictatorship". If it is about over fulfillment of production norms in Donbass "A matter of honor". If it is about the construction of Dniprelstan - "Girls of our country" and the like $[12,35]$. This model of "political theater" was focused on the government's doctrine of agitation and propaganda, used the leading slogans of the government from the standpoint of "socialist realism and "class approach". Therefore, the latest Ukrainian drama served the orders of the governing bodies for the class content of the artwork. The art form receded into the background. According to N. Kornienko, at the time of the staging of "Dictatorship", a specific "great-power" genre had already been formed $[5,286]$. Additionally he had the power to create a format of society denationalization.

Under such conditions the theatrical costume rapidly evolved from the avant-garde outrage of the complex shapes architecture and color divisions in 
the 1920s to the dominance of various options of industrial clothing in the early 1930s. Extensive variability of stage costumes sets gives way to opposition in the dressing of the characters of the opposing groups. This stylistic feature was the result of a change in the basic play composition. In the 1920s, the "hero-mass" as a collective character was formed by the plot end from the heroes of various life destinies. In the 1930s, a character that stood at the center of the plot and ensured its culmination outlooked from the category of "hero-mass". He, accordingly, distinguished for the image in details.

While during the activities of various troupes of the Theater of Coryphaeus the actors' clothes stylistically influenced the costumes choice of Ukrainophile audiences, in the 1930s theatrical costumes underwent reverse transformations the characters on stage were not different from the audience in the hall. In this way there was a reception of blurring of special imagery of theatrical system. Because theatrical artists have always felt and created the general color of the play, the theatrical model of the modernization of the USSR is called gray, as David Borovsky wrote: "There are such stable concepts: "red communism", "brown Nazism". For me, the thirties are gray. Gray on gray" [2, 142]

An exception to these phenomena was the revival of the classical tradition of making national Ukrainian costumes for performances of the historical genre, which in the 1930s was subjected to political and technological conjuncture. Nevertheless, the appearance of historical plays has created a solid foundation for the work of theater artists of many generations with special textures, silhouettes, ornaments. The stage-properties of a significant number of historical objects and accessories were restored.

The return to the Ukrainian stage of various forms of ethnic clothing of distant historical epochs restored the classic types of their semiotic codings a clear stratification of costumes, accessories, makeup of different social strata of the Cossacks; its age categories; other social strata; national features of the characters, etc.

\section{REFERENCES}

1. Bogatyrev P. G. (1975) Znaki v teatralnom iskusstve [Signs in theatrical art]. Uchenye zapiski Tartusskogo gosudarstvennogo universiteta. Trudy po znakovym sistemam. Tartu, is. 7, vol. 365, pp. 7-21. (in Russian). 
Iryna Nesen. Semiotic codes of the costume in the political theater performances in the USSR...

2. Borovskiy D. (2006) Ubegayushchee prostranstvo [Escaping space]. Moskva : EKSMO. (in Russian).

3. Veselovsjka Gh. I. (2005) Vystava odynadcjata "Dyktatura" [The eleventh play "Dictatorship"]. Veselovsjka Gh. I. Dvanadcjatj vystav Lesja Kurbasa [Twelve performances by Les Kurbas] : navchaljnyj posibnyk. Kyjiv : DCTM im. L. Kurbasa, pp. 266-293. (in Ukrainian).

4. Klekovkin O. (2012) THEATRICA. Leksykon [THEATRICA. Lexicon]. Kyjiv : Feniks. (in Ukrainian).

5. Kornienko N. (2005) Rezhisserskoe iskusstvo Lesya Kurbasa. Rekonstruktsiya (1887-1937 rr.) [Les Kurbas directing art. Reconstruction (1887-1937)]. Kiev : Gosudarstvennyy tsentr teatralnogo iskusstva imeni Lesya Kurbasa. (in Russian).

6. Leskov V. (1939) «Bogdan Khmelnitskiy» na trekh stsenakh ["Bohdan Khmelnitsky” on three stages]. Teatr, no. 7 pp. 111-123. (in Russian).

7. Mykytenko I. (1931) Dyktatura [Dictatorship]. Kharkiv: Literatura i mystectvo. (in Ukrainian).

8. Mykytenko I. (1933) Divchata nashoji krajiny [Girls of our country]. Kharkiv : Lim. (in Ukrainian).

9. Mykytenko I. (1972) Solo na flejti [Solo on the flute]. Mykytenko I. P'jesy [Plays]. Kyjiv : Dnipro, pp. 299-380. (in Ukrainian).

10. Pavi P. (2006) Slovnyk teatru [Dictionary of theater] / per. $z$ franc. M. Jakubjak. Ljviv : VC LNU imeni Ivana Franka. (in Ukrainian).

11. Piskator E. (1934) Politicheskiy teatr [Political theater]. Moskva : GIKhL. (in Russian).

12. Sverbilova T. (2007) Ivan Mykytenko (1897-1937 rr.) jak dzerkalo ukrajinsjkogho kitchu [Ivan Mykytenko (1897-1937) as a mirror of Ukrainian kitsch]. Slovo i chas, no. 9, pp. 35-47. (in Ukrainian).

13. Tokarev V. (2008) Vozvrashchenie na pedestal : istoricheskiy komentariy k filmu «Bogdan Khmelnitskiy» (1941) [Return to the pedestal: a historical commentary on the film "Bohdan Khmelnitsky" (1941)]. Istorioghrafichni doslidzhennja v Ukrajini, vol. 18, pp. 427-455. (in Russian).

14. Ghrynyshyna M. (ed.) (2012) Ukrajinsjkyj teatr XX st. : antologhija vystav [Ukrainian theater of the twentieth century: an anthology of performances]. Kyjiv : Feniks. (in Ukrainian). 
15. Centraljnyj derzhavnyj arkhiv-muzej literatury i mystectva Ukrajiny [Central State Archive-Museum of Literature and Art of Ukraine]. F. 657. Op. 1. Ref. 81.

16. Centraljnyj derzhavnyj arkhiv-muzej literatury i mystectva Ukrajiny [Central State Archive-Museum of Literature and Art of Ukraine]. F. 657. Op. 1. Ref. 132.

17. Centraljnyj derzhavnyj arkhiv-muzej literatury i mystectva Ukrajiny [Central State Archive-Museum of Literature and Art of Ukraine]. F. 657. Op. 1. Ref. 273.

18. Centraljnyj derzhavnyj arkhiv-muzej literatury i mystectva Ukrajiny [Central State Archive-Museum of Literature and Art of Ukraine]. F. 1059. Op. 1. Ref. 141. 